12. Maaros J. Anthropometric indices and physical fitness in university undergraduates with different physical activity / J. Maaros, A. Landor // Anthropol. Anz. - 2001. - V. 59, N 2. - P. 157-163.

Коровина Лидия. Состояние вегетативной нервной системы у студентов младших курсов. Проведено обследование состояния вегетативной нервной системы и анкетирование студентов младших курсов медицинской академии. Часто наблюдались отклонения показателей состояния вегетативной нервной системы от нормы. У студентов наблюдались как активация парасимпатических влияний, так и напряжение симпатических механизмов регуляции с централизацией регуляции сердечного ритма. Возрастание времени, проведенного сидя, и стажа регулярного употребления алкоголя, способствуют росту исходного вегетативного тонуса. Интенсивные занятия спортом, регулярная и продолжительная утренняя зарядка содействовали оптимизации ряда показателей состояния ВНС. Наблюдались корреляционные связи со стажем регулярного употребления алкоголя, длительностью работы за компьютером и с рядом алиментарных факторов.

Ключевые слова: вегетативная нервная система, студенты, утренняя зарядка, физические нагрузки, компьютер.

Korovina Lidiya. Autonomic Nervous System State at Junior Students. Investigation of an autonomic nervous system state and questioning of junior students of medical academy have been carried. The majority of indicators of autonomic nervous system state at young men and girls had no statistically significant differences.

Abnormalities of autonomic nervous system state indicators were observed often. Various manifestations of autonomic dysfunction were observed at $68,2 \%$ of interrogated students. Disorders of autonomic regulation are accompanied by decrease in adaptable ability, but the adaptable potential index in all students was in normal range. Both activation of parasympathetic influences and tension of sympathetic mechanisms of regulation with centralization of a heart rate regulation were observed at students also.

Total duration of additional physical training and morning exercises were the highest at students with autonomic balance and parasympathetic predominance within the limits of norm, and the lowest total duration was in group with sympathetic predominance. Intensive doing sports, regular and long morning exercises promoted optimization of some indicators of ANS state. The regular and long morning exercises have appeared an especially effective method of normalization of the cardiovascular system autonomic regulation estimated by Kerdo vegetative index.

The relatively long use of low doses of alcohol and increase in duration of time spent in sitting posture promote increase of an initial autonomic tone. These effects were observed on background of low consumption and relatively short time of alcohol intake. Reduction of a night sleep is negatively reflected in adaptable ability of an organism. Correlations with the experience of regular alcohol intake, operation time of the computer and with a number of alimentary factors were observed.

Key words: autonomic nervous system, students, morning exercises, physical activities, the computer.

Стаття надійшла до редколегії 07.02.2015 p.

УДК 616.342-002.44(043.3)

\section{Анна Маркевич Олександр Вірченко \\ Тетяна Фалалєсва \\ Костянтин Кудрявцев \\ Людмила Остапченко}

\title{
Профіль сироваткових цитокінів у щурів з експериментальним виразкоутворенням на тлі лікувального введення пролінвмісної сполуки
}

Досліджено терапевтичні властивості нової сполуки 2-(2-гідроксифенокси)ацетил)-L-пролінату натрію при стресовій, етаноловій, індометациновій та аспіриновій моделях виразкоутворення в слизовій оболонці шлунка щурів. Антивиразкові властивості сполуки були асоційовані зі зменшенням вмісту прозапальних цитокінів у крові та збільшенням вмісту антизапальних цитокінів і простагландину $\mathrm{E}_{2}$.

Ключові слова: 2-(2-гідроксифенокси)ацетил)-L-пролінат натрію, виразка шлунка, цитокіни, простагландин Е2.

(С Маркевич А., Вірченко О., Фалалєєва Т., Кудрявцев К., Остапченко Л., 2015 
Постановка наукової проблеми та їі значення. На сьогодні проблема кислотозалежних захворювань в Україні дуже актуальна. Великий сегмент у структурі цих захворювань належить ерозивновиразковим ураженням шлунка та дванадцятипалої кишки. При цьому, незважаючи на значні успіхи у дослідженні етіопатогенезу цих захворювань, значного зниження їх поширеності досягти не вдається.

Розвиток виразкового ураження в слизовій оболонці шлунка (СОШ) характеризується гострим запаленням, що викликає імунну відповідь. Поряд із клітинними механізмами імунна відповідь реалізується медіаторами міжклітинної взаємодії, тобто цитокінами, які пов'язують імунну систему 3 іншими системами організму [1]. Прозапальні цитокіни беруть участь у формуванні місцевої запальної реакції при пептичній виразці, яка асоційована з Helicobacter pylori [2]. При загостренні хронічних запальних захворювань, зокрема хвороб гастродуоденальної зони, лімфоцити та мононуклеари здатні до гіперпродукції прозапальних цитокінів. Натуральними індукторами продукції цих цитокінів $\epsilon$ мікроби та їхні токсини, що викликають розвиток запалення та формують виразкові дефекти у слизових оболонках шлунково-кишкового тракту. Висока концентрація прозапальних цитокінів у крові сприяє розвитку аутоагресії, що проявляється зростанням рівня аутоантитіл до антигенів шлунка, які здатні активувати та викликати цитотоксичні реакції проти шлункового епітелію, що порушує процеси фізіологічної регенерації [3].

В основі феномену адаптивної цитопротекції лежить активація природних механізмів адаптації слизової оболонки до впливу агресивних факторів $[4,5]$. Основним простагландином, що бере участь у процесі цитопротекції, є простагландин $\mathrm{E}_{2}\left(\Pi \Gamma \mathrm{E}_{2}\right)[6,7]$. На сьогодні точний механізм дії цитопротекторних простагландинів залишається невідомим, але для пояснення цього явища були запропоновані такі можливі варіанти: стимулююча дія цих речовин щодо вироблення шлункового слизу та секреції бікарбонатів, посилення мікроциркуляції та збільшення сульфгідрильних сполук у слизовій оболонці шлунка [6]. 3'ясовано, що простагландини не здатні захистити поверхневий шар епітелію слизової оболонки від дії подразника. Вони лише запобігають ушкодженню більш глибоких шарів за рахунок стимуляції міграції клітин слизової оболонки з непошкоджених ділянок $[8,9]$.

Сучасні експериментальні дослідження спрямовані на пошук поліфункціональних препаратів, які впливають на різні патогенетичні фактори, що лежать в основі патологій шлунково-кишкового тракту, у тому числі і виразкової хвороби, і найменшою мірою викликають побічні ефекти. Вітчизняні дослідники показали антисекреторні, антиоксидантні та гастропротективні властивості пролінвмісних пептидів [10; 11]. Поза їхньою увагою не залишилися також фенолвмісні сполуки, зокрема меланін, антивиразкова активність яких підтверджена $[12,13]$. Враховуючи наведені властивості цих сполук, на кафедрі органічної хімії Московського державного університету імені М. В. Ломоносова синтезовано нову сполуку з потенційними антивиразковими властивостями, в хімічній структурі якої поєднані одночасно пролінова та фенольна групи.

У зв'язку 3 цим ми вивчали роль цитокінів та простагландину $\mathrm{E}_{2}$ в гастропротекторній дії низькомолекулярної органічної сполуки 2-(2-гідроксифенокси)ацетил)-L-пролінату натрію.

Матеріал та методи дослідження. Для експериментів було залучено 90 білих лабораторних щурів. Всі роботи з тваринами проводились відповідно до Закону України від 21.02.2006 № 3447-IV «Про захист тварин від жорстокого поводження» та етичних норм і правил роботи 3 лабораторними тваринами (Guide for the Care and Use of Laboratory Animals, National Academy Press, Washington DC, 1996).

За добу до проведення експерименту до тварин застосовували харчову депривацію з вільним доступом до води. Досліджувана сполука синтезована в Московському державному університеті імені М.В. Ломоносова.

Тварин поділили на дев’ть груп (по 10 щурів в кожній групі): 1 - інтактні тварини; у тварин 2-9 груп моделювали експериментальне виразкоутворення. Ерозивно-виразкові ураження СОШ щурів викликали методом іммобілізаційного водоіммерсійного стресу [14], інтрагастральним введенням $96^{0}$ етанолу [15], аспірину [16] та індометацину [17]. 2, 4, 6, 8 групи - ульцерогенний чинник (стрес, етанол, аспірин, індометацин відповідно) + фізіологічний розчин (позитивний контроль); $3,5,7,9$ групи - ульцерогенний чинник (стрес, етанол, аспірин, індометацин відповідно) + 2-(2-гідроксифенокси)ацетил)-L-пролінат натрію. Досліджувану речовину вводили упродовж трьох днів після ульцерогенного чинника один раз на добу внутрішньочеревинно (в/о) в дозі 1 мг/кг. За допомогою експериментального гастроскопа при транслюмінаційному освітленні досліджували стан слизової 
оболонки шлунка при чотириразовому збільшенні. У кожному шлунку розраховували площу ерозивно-виразкових уражень.

У сироватці крові щурів вимірювали вміст інтерлейкіну (ІЛ) $1 \beta, 4,10,12 \mathrm{Bp} 40$, інтерферону $\gamma$, фактору некрозу пухлин $\alpha$, фактору росту пухлин $\beta$, простагландину $\mathrm{E}_{2}$ методом імуноферментного аналізу з використанням специфічних поліклональних антитіл (Sigma, USA) до цих молекул. У лунки 96-лункового планшета із сорбційною поверхнею іммобілізували досліджувані молекули. До них приєднували первинні антитіла, до яких приєднували вторинні антитіла 3 ферментною міткою. Оптична щільність розчину в лунці після додавання субстрату свідчила про кількість ферменту в лунці, а відповідно, і про кількість іммобілізованих молекул. Їх вміст виражали в умовних одиницях оптичної щільності.

Оскільки дані були параметричними, то порівняння різниці між контрольними та дослідними вимірами проводили за допомогою t-критерію Стьюдента для незалежних вибірок. Значущими вважали відмінності при p $\leq 0,05$. Дані представляли у вигляді середнього значення (M) i помилки середнього (m).

Виклад основного матералу й обгрунтування отриманих результатів дослідження. Оцінка уражень в шилунку шурів при введенні 2-(2-гідроксифенокси)ацетил)-L-пролінату натрію. Через три дні після водно-іммобілізаційного стресу в групі, якій впродовж цих днів вводили фізіологічний розчин, площа виразкових уражень в середньому на один шлунок складала $9 \pm 4$ мм² $^{2}$ (рис.1А). За умов лікувального введення 2-(2-гідроксифенокси)ацетил)-L-пролінат натрію площу виразкових уражень у слизовій оболонці шлунка зменшувалась на $60 \%(\mathrm{p}<0,05)$ порівняно 3 контрольною групою щурів (рис. $1 \mathrm{~A})$.

У групі щурів, яким після введення етанолу через 3 години та впродовж наступних трьох днів вводили фізіологічний розчин, площа виразкових уражень в середньому на один шлунок дорівнювала $77,9 \pm 18,9$ мм $^{2}$. Досліджувана речовина суттєво зменшила середню площу етанолових уражень (на $44,8 \%(p<0,05)$, порівняно $з$ контролем (рис. 1Б).
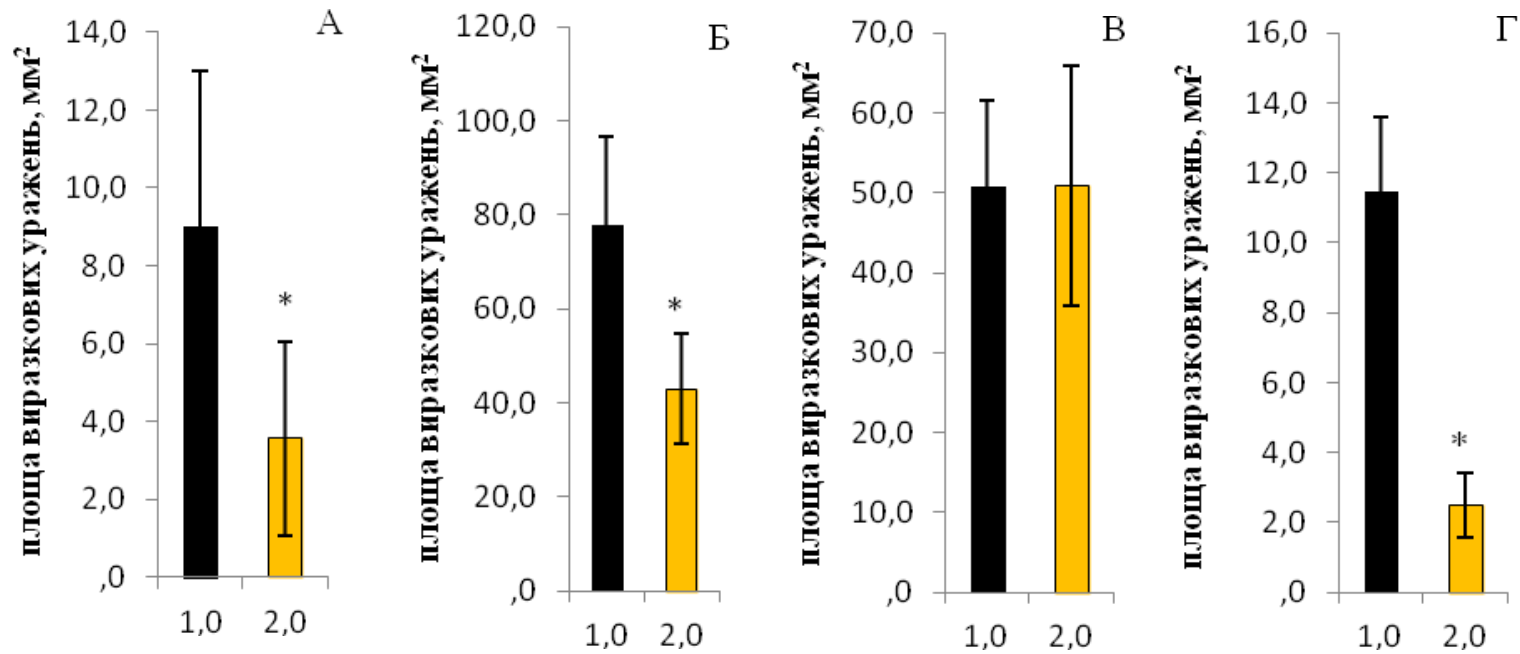

Рис. 1. Площа виразкових уражень у слизовій оболонці шлунка щурів, викликаних водноіммобілізаційним стресом (А), етанолом (Б), аспірином (В) та індометацином (Г) за умов лікувального введення низькомолекулярної органічної сполуки (1 мг/кг) (в кожній групі по 10 щурів, $\mathrm{M} \pm \mathrm{m})$ : 1 - фізіологічний розчин + ульцерогенний чинник (контроль); 2 - досліджувана сполука + ульцерогенний чинник.

Примітка: * $\mathrm{p}<0,05$ щодо контролю.

У результаті проведених досліджень встановлено, що у щурів, яким вводили аспірин та фізіоло-

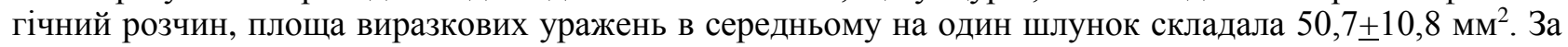
умов введення 2-(2-гідроксифенокси)ацетил)-L-пролінату натрію площа виразкових уражень становила $50,9 \pm 15$ мм² $^{2}$ що значущо не відрізнялося від контрольної групи (рис. 1В). Проте відзначити, що глибина уражень була значно меншою при терапевтичному введенні досліджуваної сполуки, що підтверджувалося гістологічним аналізом СОШ. Через три дні після введення щурам індометацину площа виразкових уражень в одному шлунку в середньому дорівнювала $11,4 \pm 2,1$ мм²$^{2}$. При введенні сполуки площа була меншою на $78,1 \%$ (p<0,05), порівняно з контрольною групою щурів (рис. $1 Г)$. 
Отже, терапевтичне застосування 2-(2-гідроксифенокси)ацетил)-L-пролінат натрію впродовж трьох днів після дії ульцерогенного чинника ефективно захищало СОШ щурів від ерозивно-виразкових уражень, викликаних стресом, етанолом, аспірином та індометацином.

Рівень простагландину $E_{2}$ в щурів при виразкоутворенні та введенні 2-(2-гідроксифенокси) ацетил) L-nролінату натрію. Ми переконалися, що стрес та етанол на нього не впливають. Вимірюючи рівень ПГЕ 2 через три дня після ульцерогенного чинника, при стресі 2-(2-гідроксифенокси)ацетил)L-пролінат натрію збільшував вміст ПГЕ 2 на $15,1 \%(\mathrm{p}<0,05)$ щодо контрольної групи щурів, яким вводили фізіологічний розчин (рис. 2). Це може бути одним із механізмів цитопротективної дії досліджуваної сполуки, адже посилення синтезу ПГЕ $є$ одним із факторів посилення секреції слизу в шлунку, який відіграє основну роль у захисті СОШ. При застосуванні НПЗП рівень ПГЕ 2 в сироватці крові щурів зменшувався, що узгоджується з даними літератури [18]. Поясненням цього явища $\epsilon$ пригнічення активності циклооксигенази під впливом НПЗП, що відповідальна за метаболізм арахідонової кислоти [18]. Досліджувана сполука підвищувала вміст ПГЕ 2 на $18,6 \%(\mathrm{p}<0,05)$ за умов індометацинової виразки та на $23,2 \%(\mathrm{p}<0,05)$ за умов введення аспірину (рис.2). Ці показники відновлювалися до значень інтактних щурів. Отже, одним із механізмів антивиразкової дії 2-(2гідроксифенокси)ацетил)-L-пролінат натрію є посилення синтезу ПГЕ 2.

Рівень прозапальних цитокінів у щурів при виразкоутворенні та введенні 2-(2-гідроксифенокси)ачетил)-L-пролінат натрію. На всіх моделях експериментального виразкоутворення реєстрували інтенсфікацію запальних процесів. Так, на третю добу фіксували підвищення рівня ІЛ-1 $\beta$ на $81,3 \%(\mathrm{p} \leq 0,01), 128,9 \%(\mathrm{p}<0,001), 84,4 \%(\mathrm{p}<0,01)$ та $118,3 \%(\mathrm{p}<0,001)$ після стресового впливу на щурів і введення етанолу, аспірину та індометацину, порівняно зі інтактними щурами (табл.1). Зміни ІЛ-12B p40 були незначними і мали різнонаправлений характер. Зокрема, за умов стресу та введення НПЗП його вміст зменшувався, що може бути частково пояснене виснаженням цієї ланки цитокінової системи. Зростання ІЛ-12В р40 відбулося лише при введенні етанолу на $10,2 \%$ ( $<0,05)$, порівняно з інтактними щурами (табл.1). Вміст ФНП- $\alpha$ збільшувався за умов стресу, етанолової, аспіринової та індометацинової виразки на 60,3\% (p<0,001), 84,6 \% (p<0,001), 79,1\% (p<0,001) та $75,4 \%(\mathrm{p}<0,01)$, порівняно з інтактними щурами (табл.1). Показник ІНФ- $\gamma$ збільшувався лише за умов найбільш сильних виразок - етанолової та індометацинової - відповідно на $17,3 \%(\mathrm{p}<0,05)$ та $31,3 \%$ (р<0,01) (табл. 1$)$.

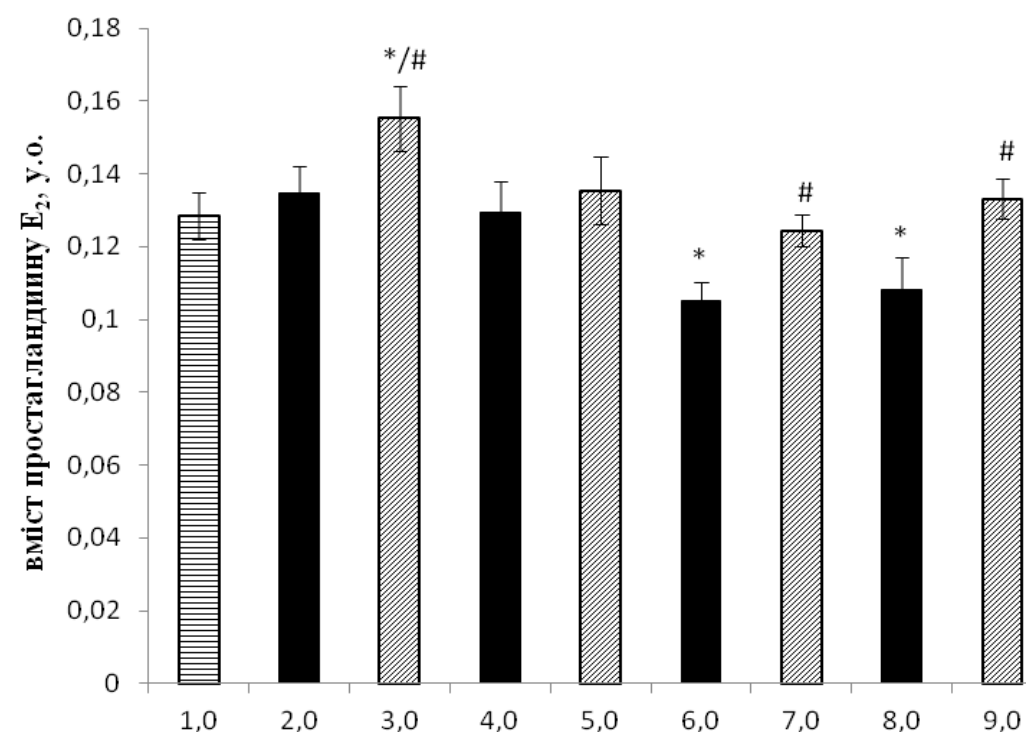

Pис. 2. Вміст простагландину Е2 в сироватці крові щурів за умов впливу ульцерогенних факторів та лікувального введення низькомолекулярної органічної сполуки (1 мг/кг) (n=10 в кожній групі, $\mathrm{M} \pm \mathrm{m})$ :

1 - інтактний контроль; $2,4,6,8$ - фізіологічний розчин + ульцерогенний чинник (відповідно стрес, етанол, індометацин, аспірин); 3, 5, 7, 9 - досліджувана сполука + ульцерогенний чинник (відповідно стрес, етанол, індометацин, аспірин)

Примітка: * $<<0,05$ щодо інтактного контролю, \# - p<0,05 щодо відповідної групи щурів, яким вводили фізіологічний розчин 
Терапевтичне введення 2-(2-гідроксифенокси)ацетил)-L-пролінату натрію зменшувало системне запалення в крові щурів за умов ульцерогенезу. ІЛ-1 $\beta$ під впливом досліджуваної сполуки зменшувався на 17,0\% (p<0,05), 34,7\% (p<0,01), 26,8\% (p<0,05), 24,0\% (p<0,05) при стресі, введенні етанолу, аспірину та індометацину порівняно зі щурами, яким вводили фізіологічний розчин (табл.1). Подібний ефект спостерігали при оцінці вмісту ФНП- $\alpha$, який під впливом субстанції зменшувався на $15,3 \%(\mathrm{p}<0,05), 17,4 \%(\mathrm{p}<0,05), 16,3 \%(\mathrm{p}<0,05)$ та $13,1 \%(\mathrm{p}<0,05)$ за умов зазначених моделей виразок щодо позитивного контролю (табл.1). Досліджувана речовина зменшувала вміст ІНФ- $\gamma$ на 22,3 \% $(\mathrm{p}<0,05)$ за умови етанолової виразки та на $14,4 \%(\mathrm{p}<0,05)$ за умови введення індометацину порівняно зі щурами, яким здійснювали ін’єкції фізіологічного розчину (табл.1).

Таблиця 1

Вміст прозапальних цитокінів в сироватці крові щурів під впливом 2-(2-гідроксифенокси)ацетил)-L-пролінату натрію (ГФП) за різних моделей виразкоутворення $(\mathrm{M} \pm \mathrm{m}, \mathrm{n}=10$ в кожній групі)

\begin{tabular}{|c|c|c|c|c|}
\hline Групи щурів & ІЛ-1及 & ІЛ-12В р40 & ФНП-а & ІНФ- $\gamma$ \\
\hline інтактні щури & $0,160 \pm 0,023$ & $0,347 \pm 0,0139$ & $0,212 \pm 0,020$ & $0,184 \pm 0,016$ \\
\hline стрес & $0,289 \pm 0,0213 * *$ & $0,279 \pm 0,0186 * * *$ & $0,340 \pm 0,018^{* *}$ & $0,186 \pm 0,006$ \\
\hline стрес+ГФП & $0,240 \pm 0,0155 * \#$ & $0,249 \pm 0,010 * * * \#$ & $0,288 \pm 0,019 * \#$ & $0,186 \pm 0,017$ \\
\hline етанол & $0,365 \pm 0,0180 * * *$ & $0,383 \pm 0,022 *$ & $0,392 \pm 0,012 * * *$ & $0,216 \pm 0,013^{*}$ \\
\hline етанол+ ГФП & $\mathbf{0 , 2 3 8} \pm \mathbf{0 , 0 2 3} * \# \#$ & $0,316 \pm 0,029 \#$ & $0,323 \pm 0,017 * \#$ & $0,168 \pm 0,010 \#$ \\
\hline аспірин & $0,294 \pm 0,014 * *$ & $0,311 \pm 0,004 *$ & $0,372 \pm 0,0124 * *$ & $0,192 \pm 0,009$ \\
\hline аспірин+ ГФП & $\mathbf{0 , 2 1 5} \pm \mathbf{0 , 0 1 3 3} * \#$ & $\mathbf{0 , 3 2 9} \pm \mathbf{0 , 0 1 4 \#}$ & $\mathbf{0 , 3 1 1} \pm \mathbf{0 , 0 2 5}$ *\# & $0,187 \pm 0,014$ \\
\hline індометацин & $0,348 \pm 0,0212 * * *$ & $0,294 \pm 0,0121^{*}$ & $0,380 \pm 0,023 * * *$ & $0,241 \pm 0,015^{* *}$ \\
\hline індометацин+ ГФП & $0,265 \pm 0,0160 * \#$ & $\mathbf{0 , 2 5 4} \pm \mathbf{0 , 0 1 2 8}$ ***\# & $\mathbf{0 , 3 3 0} \pm \mathbf{0 , 0 1 4} * \#$ & $\mathbf{0 , 2 0 7 \pm 0 , 0 1 2 \#}$ \\
\hline
\end{tabular}

Примітка: ${ }^{\mathrm{p}}<0,05,{ }^{* *} \mathrm{p}<0,01,{ }^{* * *} \mathrm{p}<0,001$ щодо інтактного контролю, \# $\mathrm{p}<0,05, \# \# \mathrm{p}<0,01$ щодо відповідної групи щурів, яким вводили фізіологічний розчин.

Вплив 2-(2-гідроксифенокси)ацетил)-L-пролінату натрію на рівень IЛ-12B p40 не однозначний: за умов етанолової та аспіринової виразки цей показник був відновлений до рівня інтактних щурів, за умов стресу та індометацину зменшувався порівняно з позитивним контролем на $10,0 \%(\mathrm{p}<0,05)$ та $8,9 \%(\mathrm{p}<0,05)$ відповідно (табл. 1$)$.

Рівень антизапальних цитокінів у щурів при виразкоутворенні та введенні 2-(2-гідроксифенокси)ачетил)-L-пролінат натрію. Вивчення вмісту протизапальних цитокінів крові показало, що у групі щурів позитивного контролю після дії усіх ульцерогенних чинників вміст ФРП- $\beta$ в сироватці крові щурів достовірно не відрізнявся від групи інтактного контролю (табл. 2).

Таблиця 2

Вміст антизапальних цитокінів у сироватці крові щурів під впливом 2-(2-гідроксифенокси)ацетил)-L-пролінату натрію (ГФП) за різних моделей виразкоутворення (M $\pm m, n=10$ в кожній групі)

\begin{tabular}{|l|c|c|c|}
\hline \multicolumn{1}{|c|}{ Групи щурів } & ІЛ-4 & IЛ-10 & ФРП- \\
\hline Інтактні щури & $0,187 \pm 0,012$ & $0,242 \pm 0,011$ & $0,310 \pm 0,006$ \\
\hline Стрес & $0,189 \pm 0,016$ & $0,273 \pm 0,014^{*}$ & $0,294 \pm 0,012$ \\
\hline Стрес+ГФП & $\mathbf{0 , 2 3 3} \pm \mathbf{0 , 0 0 8} * * \# \#$ & $\mathbf{0 , 2 3 8} \pm \mathbf{0 , 0 0 9} \#$ & $0,303 \pm 0,012$ \\
\hline Етанол & $0,244 \pm 0,010^{* *}$ & $0,291 \pm 0,013^{*}$ & $0,300 \pm 0,008$ \\
\hline Етанол+ ГФП & $0,233 \pm 0,009^{* *}$ & $0,293 \pm 0,018^{*}$ & $0,290 \pm 0,005$ \\
\hline Аспірин & $0,239 \pm 0,008^{* *}$ & $0,317 \pm 0,010^{* * *}$ & $0,269 \pm 0,006$ \\
\hline Аспірин+ ГФП & $\mathbf{0 , 2 6 3} \pm \mathbf{0 , 0 1 4} * * \#$ & $\mathbf{0 , 2 6 5} \pm \mathbf{0 , 0 1 9 \#}$ & $0,319 \pm 0,008 \#$ \\
\hline Індометацин & $0,236 \pm 0,012^{* *}$ & $0,268 \pm 0,011^{*}$ & $0,309 \pm 0,011$ \\
\hline Індометацин+ ГФП & $\mathbf{0 , 2 1 6} \pm \mathbf{0 , 0 0 7} * \#$ & $0,279 \pm 0,011^{*}$ & $0,324 \pm 0,008$ \\
\hline
\end{tabular}

Примітка: *p<0,05, **p<0,01, ***p<0,001 щодо інтактного контролю; \# $<<0,05$ щодо відповідної групи щурів, яким вводили фізіологічний розчин. 
Схожа картина спостерігалась і у групі тварин, яким вводили низькомолекулярну сполуку. Лише введення аспірину як ульцерогенного чинника та досліджуваної речовини призвело до збільшення вмісту ФРП- $\beta$ у сироватці крові щурів на 18,7 \% ( $<00,05)$ порівняно $з$ контрольною групою (табл. 2 ).

За усіх моделей виразкоутворення вміст ІЛ-10 достовірно зростав, що може бути компенсаторною реакцію цитокінової системи на посилення запалення. Досліджувана сполука значно зменшувала вміст ІЛ-10 - за умов стресу на $12,8 \%(\mathrm{p}<0,05)$ та при аспіриновій виразці на $16,4 \%(\mathrm{p}<0,05)$ щодо позитивного контролю.

Вміст ІЛ-4 зростав за умов етанолової виразки та уражень, викликаних НПЗП. Терапевтичне введення досліджуваної сполуки підвищувало вміст ІЛ-4 на 23,3 \% (p<0,01) при стресі на $12,5 \%$ $(\mathrm{p}<0,05)$ при введенні аспірину щодо позитивного контролю.

Отже, досліджувана сполука виявляла антизапальний ефект, що підтверджувалося підвищенням вмісту ІЛ-4 та відновленням вмісту ІЛ-10 щодо показників інтактних тварин.

Висновки. Низькомолекулярна органічна сполука 2-(2-гідроксифенокси)ацетил)-L-пролінат натрію при терапевтичному введенні ефективно зменшувала ураження в шлунку щурів за умов усіх експериментальних виразок.

Механізмами антиульцерогенної дії досліджуваної сполуки є ії вплив на синтез простагландину $\mathrm{E}_{2}$, а також антизапальна дія через вплив на цитокіновий профіль.

\section{Джерела та література}

1. Мудров В. П. Особенности провоспалительной цитокиновой регуляции иммунного ответа на Helicobacter pylori-инфекцию / В. П. Мудров, В. Н. Нелюбин // Иммунология. - 2004. - № 6. - С. 364-367.

2. Кононов А. В. Местный иммунный ответ на инфекцию Helicobacter pylori / А. В. Кононов // Российский журнал гастроэнтеролигии, гепатологии, колонопроктологии. - 1999. - № 2. - С. 15-22.

3. Іванова Л. М. Рівень цитокінів у хворих на пептичну виразку дванадцятипалої кишки / Л. М. Іванова, І. В. Лоскутова, Г. С. Ліпатнікова // Внутренняя медицина. - 2007. - Т. 3, № 3. - С. 5-7.

4. Ткач С. М. Современные подходы к профилактике и лечению НПВП-гастропатий / С. М. Ткач, М. П. Середа // Сучасно гастроентерологія. - 2005. - Т. 3, № 23. -С. 66-71.

5. Дзяк Г. В. Сучасний погляд на гастропатії, викликані нестероїдними протизапальними препаратами. Целекоксиб і стан секреторної функції шлунка / Г. В. Дзяк, Ю. М. Степанов, В. І. Гриценко // Сучасна гастроентерологія. - 2003. - Т. 1, № 11. - С. 4-10.

6. Гастродуоденальні ускладнення фармакотерапії нестероїдними протизапальними препаратами як актуальна проблема медицини / А. С. Свінціцький [та ін.] // Сучасна гастроентерологія. - 2001. - Т. 1, № 3. C. 22-28.

7. Laine L. Proton pump inhibitor co-therapy with nonsteroidal anti-inflammatory drugs-nice or necessary? / L. Laine // Rev Gastroenterol Disord. - 2004. - Vol. 4, Suppl 4. - P. 33-41.

8. Role of locally generated prostaglandins in adaptive gastric cytoprotection / S. J. Konturek [et al.] // Dig Dis Sci. - 1982. - Vol. 27, № 11. - P. 967-971.

9. Role of prostaglandins in the formation of aspirin-induced gastric ulcers / S. J. Konturek [et al.] // Gastroenterology. - 1981. - Vol. 80, № 1. - P. 4-9.

10. Влияние глипролинов на структурно-функциональное состояние слизистой оболочки желудка и массу тела крыс в условиях длительного введения глутамата натрия / Т. М. Фалалеева [и др.] // Физика живого. - 2010. - Т. 18, № 1. - С. 154-159.

11. Влияние пролин-содержащих пептидов Pro-Gly-Pro и его метаболитов Gly-Pro и Pro-Gly на желудочную секрецию кислоты у крыс / Т. М. Фалалеева [и др.] // Світ біології та медицини. - 2010. - № 2. C. $189-193$.

12. Влияние меланина на поражения в слизистой оболочке желудка крыс, вызванные методом нервномышечного напряжения по селье / Д. В. Голишкін [и др.] // Вісник проблем біології і медицини. - 2010. № 1. - C. 47-51.

13. Prakash Gupta R. K. In vitro antioxidant and $\mathrm{H}(+), \mathrm{K}(+)$-ATPase inhibition activities of Acalypha wilkesiana foliage extract / R. K. Prakash Gupta, Pradeepa, M. Hanumanthappa // J Pharm Bioallied Sci. - 2013. - Vol. 5, № 3. - P. 214-223.

14. Takagi K. Studies on the Drugs for Peptic Ulcer. A Reliable Method for Producing Stress Ulcer in Rats / K. Takagi, Y. Kasuya, K. Watanabe // Chem Pharm Bull (Tokyo). - 1964. - Vol.12. - P. 465-472.

15. Effect of glyprolines PGP, GP, and PG on homeostasis of gastric mucosa in rats with experimental ethanolinduced gastric ulcers / T. M. Falalyeyeva [et al.] // Bull Exp Biol Med. - 2010. - Vol.149, № 6. - P. 699701.

16. Effect of central administration of ondansetron, a 5-hydroxytryptamine-3 receptor antagonist on gastric and duodenal ulcers / S. T. Ramesh [et al.] // Fundam Clin Pharmacol. - 2009. - Vol. 23, № 3. - P. 303-309. 
17. Comparison of Indomethacin, Diclofenac and Aspirin-Induced Gastric Damage according to Age in Rats / P. J. Seo [et al.] // Gut Liver. - 2012. - Vol. 6, № 2. - P. 210-217.

18. Nonsteroidal anti-inflammatory drug-activated gene-1 plays a role in the impairing effects of cyclooxygenase inhibitors on gastric ulcer healing / R. Colucci [et al.] // J Pharmacol Exp Ther. - 2012. - Vol. 342, № 1. P. 140-149.

Маркевич Анна, Вирченко Александр, Фалалеева Татьяна, Кудрявцев Костянтин, Береговая Татьяна. Профиль сывороточных цитокинов у крыс с экспериментальным язвообразованием на фоне лечебного введения пролинсодержимого соединения. Целью работы было изучение терапевтических свойств низкомолекулярного органического соединения 2-(2-гидроксифенокси) ацетил)-L-пролината натрия при язвообразовании в желудке крыс, вызванном стрессом, этанолом, нестероидными противовоспалительными средствами (индометацином и аспирином). Исследуемое вещество вводили в дозе 1 мг/кг трижды на протяжении троих суток после ульцерогенного стимула. Установлено значительное ускорение заживления слизистой оболочки желудка крыс под влиянием используемого средства. Антиязвенные свойства соединения были ассоциированы с уменьшением содержания прововоспалительных цитокинов в крови и увеличением содержания антивоспалительных цитокинов и простагландина Е2.

Ключевые слова: 2-(2-гидроксифенокси) ацетил)-L-пролинат натрия, язва желудка, цитокины, простагландин E2.

Markevich Anna, Virchenko Oleksandr, Falalyeyeva Tetyana, Kudryavtsev Kostyantun, Beregova Tetayna. Profile of Serum Cytokines in Rats with Experimental Ulceration in the Conditions of the Therapeutic Administration of Proline Containing Compound. The purpose was to study the therapeutic properties of the low molecular weight organic compound sodium 2-(2-hydroxyphenoxy) acetyl)-L-prolinate in the conditions of gastric ulceration in rats caused by stress, ethanol, non-steroidal anti-inflammatory drugs (indomethacin and aspirin). The test substance is administered in a dose of $1 \mathrm{mg} / \mathrm{kg}$ three times for three days after the ulcerogenic stimulus. It was established a considerable acceleration of the gastric mucosa healing of rats under the influence of studied compound. Its antiulcer properties was associated with a decrease of the proinflammatory cytokines content in blood and increase of the content of anti-inflammatory cytokines and prostaglandin E2.

Key words: sodium 2-(2-hydroxyphenoxy) acetyl)-L-prolinate, gastric ulcer, cytokines, prostaglandin E2.

Стаття надійшла до редколегії 11.02.2015 p.

UDC:599.323.41:577.353

\author{
Olexiy Melnychuk \\ Olexandr Motuziuk \\ Svitlana Shvayko \\ Svitlana Zay
}

\title{
Progressive fatigue dynamic development of isolated natively musculus gastrocnemius medialis in alcoholic rats
}

In this article was investigated the development progressive fatigue dynamic of isolated natively musculus gastrocnemius medialis during tetanic contraction in alcoholic rats $(n=15)$. Registration of tetanic contraction of the isolated muscular preparation was registered in the isometric mode, during it's direct electric stimulation. The results of research shows the absence of significant changes in isolated natively musculus gastrocnemius medialis development progressive fatigue in alcoholic rats, in comparison to intact animals.

Key words: alcohol intoxication, alcoholic rats, muscle fatigue, musculus gastrocnemius.

Introduction. The skeletal muscles continuously adapt to the changes of it's environment by the way of gene expression and stability of protein modifycation, which influence on a physiological function and muscles mass. However, usually, mechanical stress goes out outside of muscles adaptation possibilities and causes their sharp damage.

(C) Melnychuk O., Motuziuk O., Shvayko S., Zay S., 2015 